\title{
Mediterranean pine and oak distribution in southern Spain: Is there a mismatch between regeneration and adult distribution?
}

\author{
Itziar R. Urbieta, Luís V. García, Miguel A. Zavala \& Teodoro Marañón
}

\author{
Keywords \\ Distribution range; Holm oak; Mediterranean \\ forest; Niche expansion; Pinus spp.; Quercus \\ spp.; Regeneration dynamics \\ Received 27 July 2009 \\ Accepted 8 September 2010 \\ Co-ordinating Editor: Alessandro Chiarucci
}

\begin{abstract}
Questions: What is the current distribution of pine and oak species along environmental gradients in southern Spain? Do pine and oak regeneration niches differ from the environmental niches of adults? Is oak species regeneration favoured under the canopy of pine forests?

Location: Forest areas of Andalusia ( $87600 \mathrm{~km}^{2}$, southern Spain).

Methods: We compiled extensive forest inventory data to explore differences in abundance (basal area, $\mathrm{m}^{2} \mathrm{ha}^{-1}$ ) patterns of adults $(\mathrm{dbh}>7.4 \mathrm{~cm})$ and regeneration ( $\mathrm{dbh} \leq 7.4 \mathrm{~cm}$ ) of five pine and five oak species. Canonical correspondence analysis (CCA) and generalized linear models were applied to explore species-environment relationships along climatic, edaphic, topographic and fire-frequency gradients.

Results: Both pines and oaks segregated along complex environmental gradients, with pines generally dominating in more severe (colder and drier) environments, while oaks dominated in milder, wetter winter areas. In 40-55\% of mature pine stands there was a lack of regeneration in the understorey, while in two oak species (Q. suber and Q. canariensis) 70\% of stands did not show regeneration. Pine recruits were found at a higher frequency and abundance under the canopy of their congeners, whereas some oaks (Q. ilex) had greater regeneration under mixed pine-oak canopies.
\end{abstract}

Conclusions: Climatic limitations and soil properties partly explained the regional distribution of pines and oaks. We found evidence for an upward shift of $Q$. ilex recruits towards areas with colder conditions in pine forests, which could be explained by a possible facilitative effect of the pine canopy on seedling establishment.

\section{Introduction}

A fundamental issue in ecology is understanding how broad environmental drivers, local site factors and disturbance processes interact to control patterns and changes in biological communities (Huston 1994). The distribution of vegetation is largely controlled by climate - chiefly water and energy (Currie \& Paquin 1987) - and by historical constraints such as geographical dispersal limitation (Svenning \& Skov 2005). On a more local scale, environmental constraints interact with biological processes, including species ability to reproduce and disperse (Kohyama 1993). Plant-plant interactions, such as competition for resources or positive interactions (facilitation), can also influence the distribution of species (Callaway \& Walker 1997).
Plant resources (e.g. light and water availability) can change significantly throughout the life history of plants (Cavender-Bares \& Bazzaz 2000). Tree seedlings have smaller and shallower root systems than mature trees, and occur in soil layers more susceptible to drying from soil surface evaporation and transpiration of neighbouring trees and the herbaceous layer (Kolb \& Stone 2000). Moreover, changes in carbon and water relationships (e.g. drought response strategies and differences in photosynthetic capacity) between seedlings, saplings and mature trees (e.g. Mediavilla \& Escudero 2004) may result in ontogenetic conflicts (sensu Schupp 1995). While the distribution of adult trees is mainly a reflection of a response to past (climatic, management, etc.) conditions, 
the observation of species at a young life stage (seedlings) depicts a response to the present environment. Consequently, effective regeneration might be distant from, or under different resource conditions, to that of adults. Particularly, in heterogeneous landscapes, young individuals are associated with certain microhabitats within a forest (Gómez-Aparicio et al. 2005), or located at a certain distance from forest patches as a result of long-distance dispersal events (Pons \& Pausas 2006). The assessment of how different life stages of species vary along environmental gradients, particularly how abundant forest regeneration is and how seedlings respond to environmental limitation (e.g. Bansal \& Germino 2010), can indicate whether a population is declining, stable or expanding. Furthermore, it is essential for predicting future stand dynamics under eventual changes in climatic or management conditions.

In Mediterranean forests, regeneration is scarce due essentially to seed and seedling establishment limitation (e.g. Acácio et al. 2008; Mendoza et al. 2009), driven mainly by environmental constraints such as drought (Castro et al. 2004), high pressure from herbivores (Baraza et al. 2006) and certain management techniques, such as understorey clearance for open-woodland formation (Pulido et al. 2001). There have been numerous experimental studies describing biotic and abiotic factors that limit Mediterranean forest regeneration along resource gradients at local scales (e.g. Espelta et al. 1995; Castro et al. 2004; Urbieta et al. 2008a; Pérez-Ramos et al. 2010), yet few studies have attempted to evaluate the state of forest regeneration (e.g. Plieninger et al. 2010), or to study the differences between regeneration and adult distribution along environmental gradients on a large scale (e.g. Lenoir et al. 2009).

The present study analyses the relationship between the abundance of five oak (Quercus spp.) and five pine (Pinus spp.) species and various key environmental factors in southern Spain, based on forest inventory data linked to independent environmental information. The aim was to assess whether environmental correlates (assumed to be related with ecological requirements) of adult canopy trees differed from those of regeneration (i.e. seedlings and saplings) of the same species. In particular, we focused on the assessment of how abundant was oak regeneration under the canopy of pines. Forest management, particularly throughout the 20th century, relied on the establishment of tree cover for soil conservation purposes by means of extensive plantations of fast-growing pioneer species such as pines, assuming this species would facilitate the establishment (artificial or natural) of late-successional species such as oaks (Pausas et al. 2004). However, the role that pine plantations, which are widespread in lowlands and mountain ranges, have played in the establishment of late-successional hardwood species is still subject to open debate (Maestre \& Cortina 2004; Pausas et al. 2004; Gómez-Aparicio et al. 2009). Furthermore, a major trend in the current forest management policy is the conversion of planted coniferous forests into native broad-leaved forests (e.g. Onaindia $\delta$ Mitxelena 2009). Thus, exploring pine-oak forest structure along abiotic and biotic gradients can provide valuable information for the development of efficient forest management and restoration plans.

Specifically, the main objectives of this study were: (i) to identify the principal factors (climatic, topographic, soil characteristics and fire frequency) determining pine and oak species abundance distribution; (ii) to analyse whether species regeneration niches differed from adult environmental niches with respect to critical environmental gradients; and (iii) to examine if there was evidence supporting that oak regeneration was favoured under the canopy of pine forests.

\section{Methods}

\section{Study area and species}

The study area is located in Andalusia (southern Spain), a region of $\sim 87600 \mathrm{~km}^{2}$ which encompasses a large altitudinal gradient $(0-3480 \mathrm{~m})$ (Fig. 1). Mountain systems surround the region and lie on both sides of the Guadalquivir River depression, with Palaeozoic and siliceous materials to the north, and sedimentary materials (limestone and sandstone) to the south. The climate is Mediterranean but quite variable, with mean annual precipitation between 140 and $2153 \mathrm{~mm}$. Dry, warm summers (average July temperature: $15^{\circ} \mathrm{C}$ to $27^{\circ} \mathrm{C}$ ) are followed by fairly cold winters (average January temperature: $-2^{\circ} \mathrm{C}$ to $12^{\circ} \mathrm{C}$; Spanish Agency of Meteorology). Forest areas are scarce in the more arid southeastern territory, and have been almost entirely eliminated from the Guadalquivir valley by agricultural transformation (Fig. 1). For the purpose of this study, we focused on five oak (Quercus) and five pine (Pinus) species: the evergreens Quercus ilex (holm oak) and Q. suber (cork oak), winter deciduous Q. pyrenaica (Pyrenean oak), and semi-deciduous Q. faginea (Portuguese oak) and Q. canariensis (Algerian oak); Pinus halepensis (Aleppo pine), P. pinaster (maritime pine), $P$. pinea (stone pine), and the montane species $P$. nigra (black pine) and P. sylvestris (Scots pine) (Fig. 1). Some planted pine stands were also included due to the difficulty in disentangling their true origin. Nevertheless, this bias affects only adult pine observations, not regeneration. Exotic pine species (P. radiata and P. canariensis), present in $<1 \%$ of plots, were excluded from the analyses.

\section{Data set}

We analysed a large data set of the Spanish Second Forest Inventory (SSFI) conducted in forest areas of Andalusia 


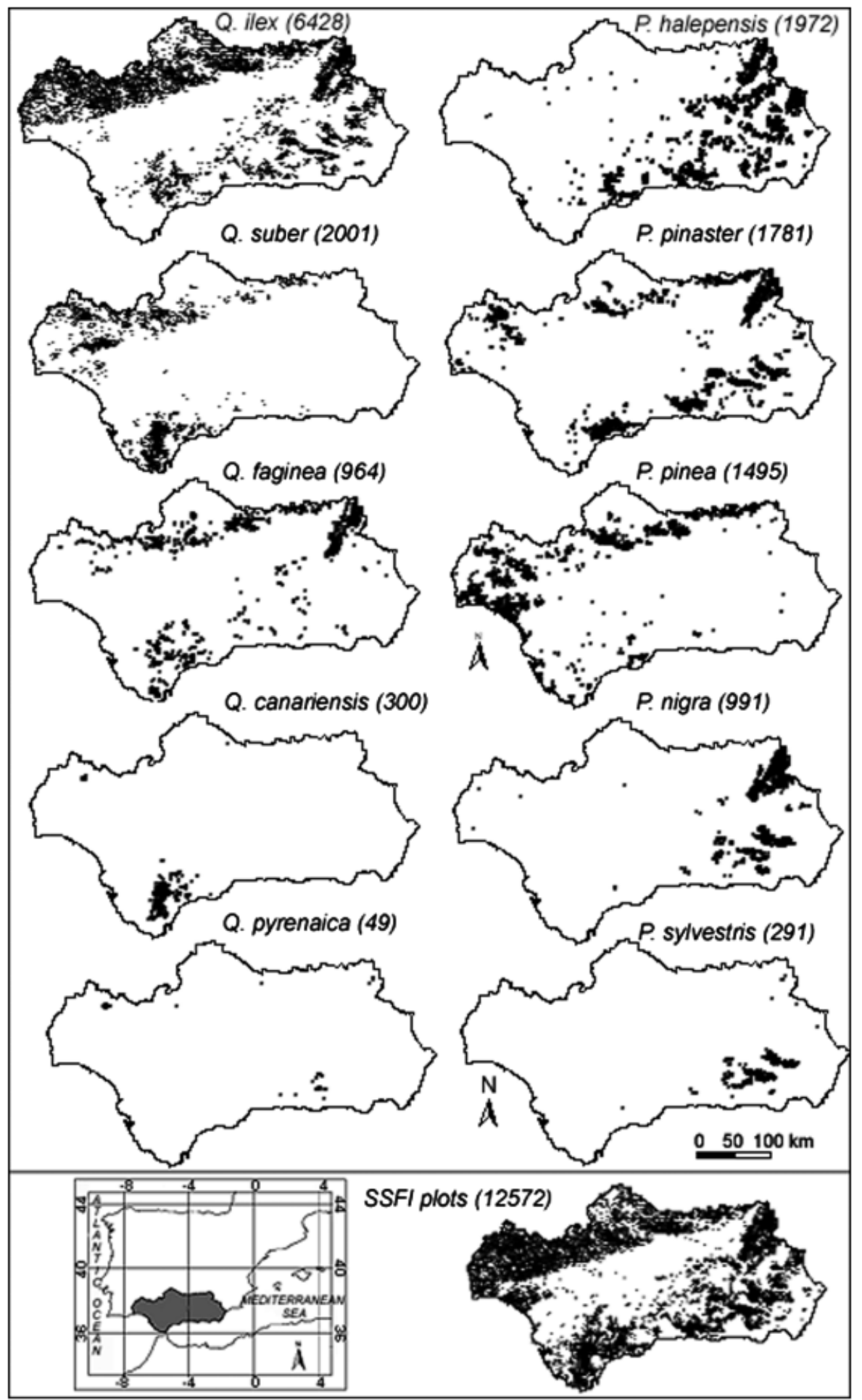

Fig. 1. Quercus and Pinus species distribution in Andalusia (southern Spain) based on the Spanish Second Forest Inventory (SSFI) plots. The number of SSFI plots per species is indicated in brackets.

during 1994-1996 (MMA 1996). Prior to the analyses, we checked for the geographic position of all inventoried plots, superimposing them onto digital orthophotographs
(JA 2003). Plots with georeferencing errors were discarded for the analyses; the result was a total of 12572 plots. SSFI plots were circular, of various concentric radii 
up to $25 \mathrm{~m}$, with an intensity of approximately one plot per square kilometre. Trunk diameter at breast height (dbh, $1.30 \mathrm{~m}$ ) of all trees with a dbh greater than $7.4 \mathrm{~cm}$ was measured as two perpendicular measurements using callipers. For saplings (dbh $2.5-7.4 \mathrm{~cm}$ ), the number of individuals (density) was estimated, and for seedlings $(\mathrm{dbh}<2.5 \mathrm{~cm})$ their presence or absence was recorded within a $5-\mathrm{m}$ radius of the plot.

\section{Stand structure}

In each plot, species basal area was calculated as the sum of the basal areas $\left(\mathrm{m}^{2}\right)$ of all trees of the same species, assuming a circular cross-section of the trunk, and then expressed on a unit area basis in $\mathrm{m}^{2} \mathrm{ha}^{-1}$. For saplings, we assumed a mean diameter of $5 \mathrm{~cm}$ per individual for basal area calculation. In plots where the presence of seedlings was recorded, we assumed at least one seedling with an average diameter of $1.25 \mathrm{~cm}$, in order to differentiate presence from absence. In the analyses, we first considered species total abundance as the basal area of all inventoried tree sizes. Then, we partitioned this value, differentiating the basal area of adults (a), i.e. trees with $\mathrm{dbh}>7.4 \mathrm{~cm}$, and the estimated basal area of regeneration $(r)$, i.e. individuals with $\mathrm{dbh} \leq 7.4 \mathrm{~cm}$, including saplings and seedlings. In the case of resprouting oak species, regeneration includes ramets.

Each inventoried plot was characterized with independent environmental data. Raster maps and sampling locations (UTM coordinates of plots) were combined to determine the values of each abiotic variable in each plot, using ArcView 3.2 (ESRI (Environmental Systems Research Institute) Inc., 2000. ArcView GIS, version 3.2. Redlands, USA). The variables included climatic and topographic factors, soil characteristics and fire frequency, and were calculated as described below.

\section{Climatic factors}

Climatic data with a spatial resolution of $1 \mathrm{~km}$ were provided by the Spanish Agency of Meteorology as an interpolation (kriging) of the information (period 1971 to 2000) from 143 primary meteorological stations, 1504 thermometric stations and 4835 pluviometric stations (Spanish Agency of Meteorology, unpublished). We assigned the following climatic variables to each SSFI plot: annual mean precipitation (PANU) (mm), spring (PSPR), summer (PSUM), autumn (PAUT) and winter (PWIN) precipitation (in $\mathrm{mm}$ ); annual mean radiation (RADANU) $\left(\mathrm{kW} \mathrm{h} \mathrm{m}^{-2}\right)$ and radiation per season (RADSPR, RADSUM, RADAUT, RADWIN); annual mean temperature (TANU) $\left({ }^{\circ} \mathrm{C}\right)$, average temperature of the warmest month (TWM), average temperature of the coldest month (TCM) and thermal oscillation (TOSIC). Annual potential evapotranspiration (TPET) $(\mathrm{mm})$ was obtained as a function of mean temperature (Thornthwaite 1948). Computing monthly differences between $\mathrm{P}$ and PET, we calculated annual water surplus (TSUP) as the sum of positive differences, annual water deficit (TDEF) as the sum of negative differences, and drought length (DL) as the number of months in which PET exceeded P.

Topographic factors

For each SSFI plot we derived altitude (ALT) (m), slope (SLOP) (degrees) and aspect (ASP) as degrees with respect to north from a 20-m digital elevation model (DEM). Aspect directional data were subjected to inverse polar transformation, which produced two Cartesian variables accounting for slope orientation in the south-to-north (SN) and west-to-east (WE) directions.

\section{Soil factors}

We assigned the dominant soil typological unit (FAOUNESCO soil legend) to each SSFI plot, from the soil geographical database of Europe, scale 1/1 000000 (European Soil Bureau. 1999. European soil database v 1.0. Ispra, Italy). Using the FAO-UNESCO definition criteria for the different soil units, we derived ordinal categories for some relevant soil properties: soil depth (SDEPTH); soil base saturation (SBASE); presence of $\mathrm{CaCO}_{3}$ (or, at a few sites, other calcium-rich materials such as gypsum) (SCALC). We also derived estimates for overall soil water capacity (SAWC) (mm), using estimates for topsoil and subsoil water capacity (European Soil Bureau. 1999. European soil database v. 1.0. Ispra, Italy).

\section{Fire frequency}

Cartographic layers of fire surface, with a cover of at least 10 ha, were used, based on Landsat images of Andalusia at the end of each fire campaign (REDIAM, Andalusian Government, unpublished). Fire occurrence (FIRE) between 1987 and 2002, expressed as frequency, was assigned to each SSFI plot.

\section{Statistical analyses \\ Species abundance patterns}

Multivariate analysis, together with likelihood methods and model selection, were combined to identify the principal environmental factors that determined pine and oak species distribution. First, we applied an indirect gradient analysis - a detrended correspondence analysis (DCA) - to estimate the main environmental gradients 
and to decide whether linear or unimodal direct gradient methods were better suited to examine species-environment relationships (Leps \& Smilauer 2003). Second, a canonical correspondence analysis (CCA) (ter Braak 1986) was carried out to study the relationship between species abundance (with all inventoried individuals) and environmental variables, using CANOCO v4.5 (ter Braak \& Smilauer 2002). Basal area data were $\log$ transformed $(\log x+1)$ to minimize the skewness of species abundance distribution. To avoid artifacts, results were checked for uni- and multivariate extreme values (ter Braak \& Smilauer 2002). Manual selection and Monte-Carlo permutation tests, with 999 unrestricted permutations, were used for selection of the most significant variables, as well as to evaluate the significance of the extracted axes. The step-wise option was used to exclude highly redundant variables (Økland \& Eilertsen 1994). Significance was fixed at the 0.05 level throughout the study, and corrections to limit type I error inflation were performed according to García (2004).

Third, we analysed how pine and oak species overall abundance varied along the main CCA axes and the most relevant environmental variables, fitting generalized linear models (GLM) using the CanoDraw program (ter Braak \& Smilauer 2002). Because of the skewed distribution of species abundance data and the large quantity of absence data (i.e. species basal area equal to zero), we assumed a Poisson distribution, log-link option, according to Leps \& Smilauer (2003). We tested for linear and bellshaped unimodal response of species along the underlying environmental gradients by comparing the value of Akaike's information criterion (AIC) (Akaike 1992) to the AIC of a null model (i.e. intercept-only model) (Leps $\delta$ Smilauer 2003). Competing models for each species were compared with $\triangle \mathrm{AIC}$, which is defined for each Model $_{\mathrm{i}}$ as $\mathrm{AIC}_{\mathrm{i}}$ minus $\mathrm{AIC}_{\text {minimum, }}$ i.e. the model with the strongest empirical support has the minimum AIC, and thus its $\Delta \mathrm{AIC}=0$ (Akaike 1992)

\section{Species regeneration patterns}

We analysed whether the distribution of forest regeneration $(r)$ (individuals with $\mathrm{dbh} \leq 7.4 \mathrm{~cm}$ ) of each species differed from that of adults $(a)(\mathrm{dbh}>7.4 \mathrm{~cm})$ of the same species. We projected the distribution of adults and regeneration on the CCA bi-plot, and fitted GLMs along the main CCA axes and the most relevant environmental variables, following the same procedure as for species overall niche. The central positions (optima) of $r$ and $a$ were compared through the overlapping of their $95 \%$ confidence intervals (CI). The optimum was measured as the value of the abiotic gradient where species $r$ and $a$ reached their maximum abundance, and was calculated using parameters of the unimodal model with the Cano-
Draw program (ter Braak \& Smilauer 2002). Furthermore, for $r$ models we tested for the effect of total stand basal area on species regeneration abundance using STATISTICA v 6.1. (StatSoft, Inc., http://www.statsoft.com).

To explore whether oak regeneration was favoured under the canopy of pine forests (and a possible reciprocal trend), we classified forest stands (SSFI plots) into five habitat types: Open, when the stand basal area was $<\mathrm{l} \mathrm{m}^{2} \mathrm{ha}^{-1}$ (this included plots without tree cover but that may have had shrubby vegetation, although this could not be estimated from the data); Quercus, when the basal area of oaks was $>80 \%$ of total stand basal area and no pines were present; Pinus, when the basal area of pines was $>80 \%$ and no oaks were present; Mixed Quercus-Pinus stands, when the basal area of pines plus oaks represented at least $25 \%$ of the stand basal area; and finally, Other species habitat included plots where the basal area of other species was $>80 \%$. Regeneration abundance in each habitat was compared with the reference $(\mathrm{R})$ habitat (i.e. that with conspecifics) by means of a non-parametric permutationbased ANOVA. We used a dummy variable coding for the different habitats together with the permutation test facilities implemented in CANOCO v4.5, which allowed us to overcome the parametric test assumptions, as described in ter Braak \& Smilauer (2002). The ANOVA was performed using the spatial variables as co-variables to remove the spatial dependence of the data, as described in Borcard et al. (1992). Using the same procedure, we tested if, for those species that showed differences in regeneration and adult distribution, the effect of key environmental variables on regeneration was conditioned by the habitat type, i.e. whether significant interactions existed between environmental variables and habitat types.

\section{Results}

\section{Species abundance along environmental gradients}

Oaks and pines were present in approximately $70 \%$ of the total SSFI plots, and their distribution along the studied environmental gradients was non-random, as shown by DCA and CCA analyses (Table 1, Fig. 2). The first three DCA axes accounted for $25 \%$ of the overall species variance, and their length (6.1, 4.3 and 4.3, respectively) indicated that species responses to environmental variations were mainly unimodal (ter Braak \& Smilauer 2002). The first axis (with $11 \%$ of variance) was a complex gradient positively correlated to increased soil calcium $(r=0.66)$, summer radiation $(r=0.59)$ and summer precipitation $(r=0.52)$, while it was negatively related to temperature gradients, TCM ( $r=$ $-0.78)$ and TWM $(r=-0.59)$. It was also closely related to changes in altitude $(r=0.77)$, suggesting that this main trend in species distribution is associated with temperature/ radiation and precipitation changes observed along 
Table 1. Explained variance, correlation with environmental variables and fitted variance per species for each of the first three axes of the canonical correspondence analysis (CCA).

\begin{tabular}{|c|c|c|c|}
\hline & CCA Axis 1 & CCA Axis 2 & CCA Axis 3 \\
\hline Eigenvalues & 0.58 & 0.35 & 0.18 \\
\hline Species-environment correlations & 0.82 & 0.65 & 0.48 \\
\hline Explained variance (\% species data) & 9.50 & 5.90 & 3.00 \\
\hline Cumulative $(\%)$ species data & 9.50 & 15.40 & 18.40 \\
\hline Cumulative (\%) species-envir. relation & 44.60 & 72.40 & 86.60 \\
\hline \multicolumn{4}{|l|}{ Weighted correlations } \\
\hline Slope $\left(S L O P,{ }^{\circ}\right)$ & -0.32 & -0.18 & 0.42 \\
\hline Summer precipitation (PSUM, mm) & -0.69 & -0.33 & -0.23 \\
\hline Winter precipitation (PWIN, mm) & 0.54 & -0.70 & 0.17 \\
\hline Drought length (DL, months) & 0.22 & 0.67 & 0.27 \\
\hline Summer radiation (RADSUM, $\mathrm{kW} \mathrm{h} \mathrm{m}^{-2}$ ) & -0.56 & 0.35 & -0.56 \\
\hline Temperature of the warmest month $\left(\mathrm{TWM}^{\circ}{ }^{\circ} \mathrm{C}\right)$ & 0.70 & 0.52 & -0.31 \\
\hline Temperature of the coldest month $\left(\mathrm{TCM},{ }^{\circ} \mathrm{C}\right)$ & 0.90 & 0.20 & 0.24 \\
\hline Soil base saturation (SBASE) & -0.45 & 0.22 & 0.05 \\
\hline Soil calcium (SCALC) & -0.59 & 0.15 & 0.46 \\
\hline Soil depth (SDEPTH) & 0.56 & 0.32 & -0.005 \\
\hline Soil water capacity (SAWC) & 0.20 & 0.46 & -0.19 \\
\hline \multicolumn{4}{|l|}{ Fitted variance $(\%$, cumulative $)$} \\
\hline Q. ilex & 0.97 & 4.00 & 20.20 \\
\hline Q. suber & 29.82 & 41.12 & 44.81 \\
\hline Q. faginea & 0.48 & 1.11 & 1.18 \\
\hline Q. canariensis & 3.04 & 6.16 & 6.96 \\
\hline Q. pyrenaica & 0.01 & 0.02 & 0.02 \\
\hline P. halepensis & 11.88 & 23.09 & 32.58 \\
\hline P. pinaster & 2.79 & 4.12 & 4.12 \\
\hline P. pinea & 7.39 & 15.13 & 15.16 \\
\hline P. nigra & 25.89 & 39.15 & 39.22 \\
\hline P. sylvestris & 2.24 & 3.74 & 3.95 \\
\hline
\end{tabular}

altitudinal gradients. The three main CCA axes explained $18.4 \%$ of the overall species data (Table 1 ). Climatic variables were the most significant predictors, followed by soil and topographic variables, while fire frequency did not enter into the model. Axis 1 was strongly and positively correlated with the temperature gradients, and negatively with summer precipitation and radiation (see $r$ values in Table 1). Because altitude was closely and negatively related to temperature and CCA Axis $1(r=-0.90)$, it was used as a supplementary variable. Variability of edaphic factors (soil calcium, base saturation and depth) and slope was also captured in Axis 1 (Table 1, Fig. 2a). CCA Axis 2 was correlated mainly with water availability conditions positively with drought length and negatively with winter precipitation - and showed a positive correlation with soil water-storage capacity and summer temperature. Finally, CCA Axis 3 was negatively correlated with summer radiation and positively with calcium content and slope (Table 1). The proportion of variance of species abundance explained by CCA Axes 1 and 2 was high for Q. suber, $Q$. canariensis, P. pinea and P. nigra, while CCA Axis 3 contributed to increase the variance explained for $Q$. ilex and P. halepensis (Table 1).
In general, oaks and pines segregated along Axis 1, oaks being located towards more positive values of the gradient with milder conditions and deeper soils (Fig. 3a), and pines towards the negative side - i.e. towards higher and colder areas with increased summer precipitation and radiation (Fig. 3b). Axis 2 stressed the differences between certain species, such as $P$. halepensis and $P$. pinea located at the driest part of the gradient as opposed to Q. canariensis in the wettest end (see Appendix S1 for the distribution of species along CCA Axis 2).

According to GLM fits, the complex gradient defined by Axis 1 best explained (i.e. $\triangle \mathrm{AIC}=0$ ) the distribution of four species, Q. suber, Q. canariensis, Q. pyrenaica and $P$. halepensis; while $P$. pinaster response was associated to Axis 2, and $Q$. ilex to Axis 3 (see Appendix S2 for model fits). The distribution of the other species fitted better (lowest AIC) to single environmental variables: $Q$. faginea to increased winter precipitation and $P$. pinea, $P$. sylvestris and $P$. nigra to temperature and summer precipitation (i.e. altitudinal) gradients (Appendix S2). Species with more-limited distribution (Q. pyrenaica and P. sylvestris) had a low model success, and thus their results should be viewed with caution. The ranges of environmental conditions (for each 
(a)

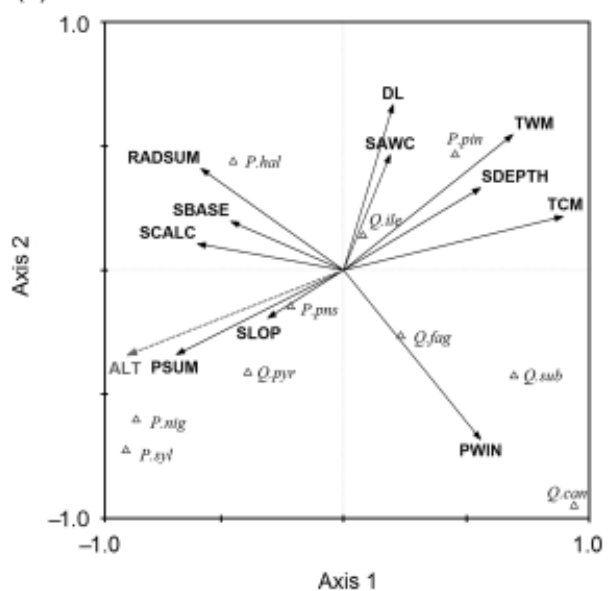

(b)

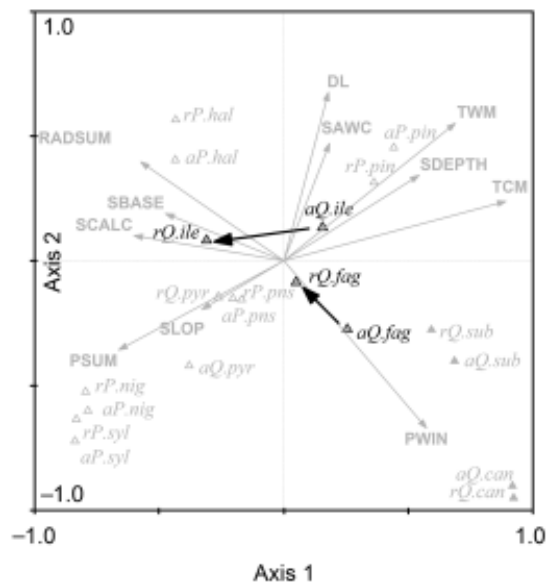

Fig. 2. (a) CCA bi-plot (Axes 1 and 2) of the environmental variables and the distribution of pines and oaks (all inventoried individuals included). Altitude (dashed line) is shown as supplementary variable. (b) CCA bi-plot separately showing regeneration ( $r$ ) and adult (a) centroids for each species. For $Q$. ilex and Q. faginea adult and regeneration distributions are distant, with no overlap at 95\% confidence intervals (see text, and Table 2 for Q. ilex models).
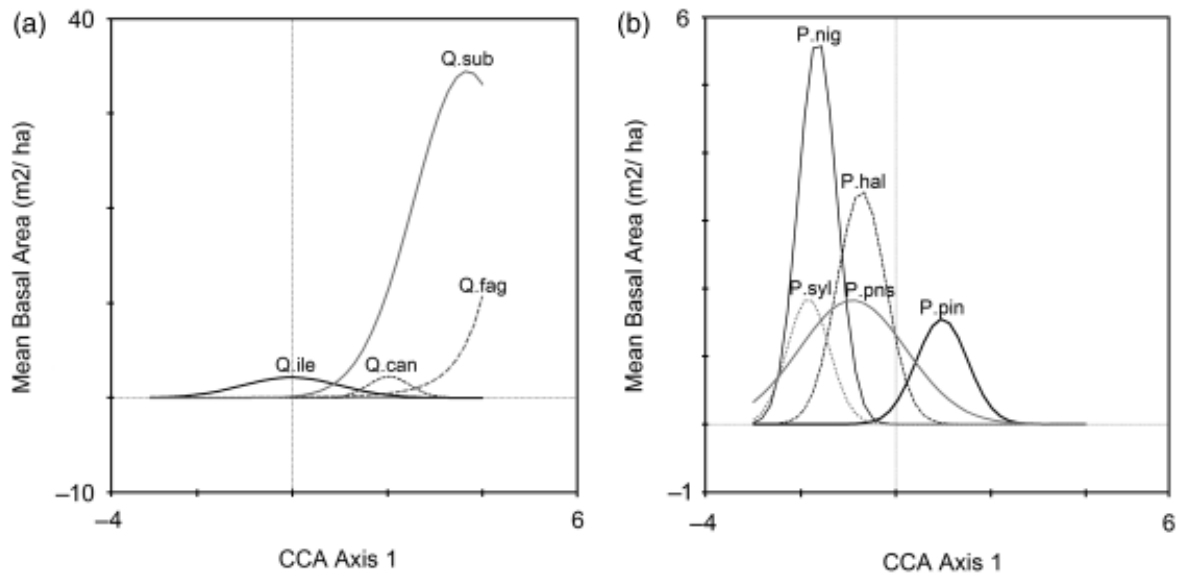

Fig. 3. Quercus (a) and Pinus (b) species abundance (mean basal area, $\mathrm{m}^{2} \mathrm{ha}^{-1}$ ) variation along CCA Axis 1 according to GLM fits. Q. pyrenaica is not shown due to its low model fit.

of the initially selected abiotic factors) for pine and oak species are summarized in Appendix S3.

\section{Species regeneration along environmental gradients}

A high proportion of pine and oak forest stands showed null regeneration, i.e. absence of seedling and saplings in their understorey. For the five pine species, some 40-55\% of the SSFI plots with presence of the species were mature stands without regeneration. Among oaks, the percentage of regeneration failure varied from $60-70 \%$ of the SSFI plots for Q. suber and Q. canariensis to $30-40 \%$ for $Q$. ilex and Q. faginea, and ca. 25\% for Q. pyrenaica. When we compared the distribution of adults $(a)$ and regeneration $(r)$ of species along the environmental gradients, the models showed that pines generally had closely associated distribution areas between $a$ and $r$ along the main CCA axes (i.e. 95\% CI of the optima overlapped in all cases; models not shown) (Fig. 2b). Conversely, for some oak species $-Q$.ilex and $Q$. faginea $-a$ and $r$ diverged when their distributions were projected in the CCA bi-plot (Fig. 2b). Specifically, for $Q$. ilex the optimum of $a$ and $r$ did not overlap along the main CCA axes, with the maximum regeneration located towards more negative values of CCA Axis 1, and more-positive values of CCA Axis 3 (Table 2). According to GLM best fits, Q. ilex regeneration was best explained $(\triangle \mathrm{AIC}=0)$ by the gradient of temperature of the coldest month (TCM). In particular, the optimum of $a$ and $r$ did not overlap along the TCM gradient, with regeneration of the species found in colder areas (optimum at $3.7^{\circ} \mathrm{C}$ ) than for adults (optimum at $7.2^{\circ} \mathrm{C}$ ) (Table 2). Furthermore, in those areas, mean 
Table 2. Parameter estimates and comparison of significant models for $Q$. ilex regeneration $(r)$ and adults (a). Note: Optimum and tolerance (average curve width along the gradient) of species unimodal response are shown. Regression coefficients (intercept and first and second order parameters) of all significant models are reported. Models for regeneration $(r)$ and adults (a), are compared with AIC (Akaike's information criteria). The best models (lowest AIC, $\triangle A I C=0$ ) for $r$ and $a$ are indicated in bold type. AIC of the null models (i.e. mean or intercept-only model) are shown for comparison. Abbreviations: $\mathrm{Cl}$, confidence interval; TCM, temperature of the coldest month; CCA AXIS, canonical correspondence analysis axis; RADSUM, summer radiation.

\begin{tabular}{|c|c|c|c|c|c|c|c|c|c|c|}
\hline Species & Life stage & Factor & Optimum & $95 \% \mathrm{Cl}$ (Opt.) & Tolerance & Intercept & Coeff $X$ & Coeff $X^{2}$ & $\mathrm{AIC}$ & $\overline{\Delta \mathrm{AIC}}$ \\
\hline \multirow[t]{10}{*}{ Q. ilex } & $r$ & $\operatorname{TCM}\left({ }^{\circ} \mathrm{C}\right)$ & 3.73 & $(3.417,3.989)$ & 2.46 & -1.758 & 0.616 & -0.083 & 8577 & 0 \\
\hline & $a$ & $\operatorname{TCM}\left({ }^{\circ} \mathrm{C}\right)$ & 7.23 & $(7.177,7.288)$ & 2.38 & -3.967 & 1.273 & -0.088 & 32223 & 2048 \\
\hline & $r$ & CCA AXIS 3 & -0.12 & $(-0.198,-0.054)$ & 1.17 & -1.204 & -0.091 & -0.366 & 10019 & 1442 \\
\hline & $a$ & CCA AXIS 3 & -4.06 & $(-5.306,-3.303)$ & 2.45 & 0.118 & -0.679 & -0.084 & 30175 & 0 \\
\hline & $r$ & CCA AXIS 1 & -1.43 & $(-1.663,-1.260)$ & 1.16 & -1.482 & -1.056 & -0.369 & 8967 & 390 \\
\hline & $a$ & CCA AXIS 1 & 0.20 & $(0.179,0.223)$ & 0.91 & 0.645 & 0.242 & -0.603 & 31932 & 1757 \\
\hline & r & RADSUM $\left(\mathrm{kW} \mathrm{h} \mathrm{m}^{-2}\right)$ & 7.3 & $(7.081,7.954)$ & 0.38 & -183.1 & 50.16 & -3.435 & 9617 & 1040 \\
\hline & $a$ & RADSUM $\left(\mathrm{kW} \mathrm{h} \mathrm{m}^{-2}\right)$ & 6.67 & $(6.662,6.677)$ & 0.18 & -655.1 & 196.64 & -14.74 & 32342 & 2167 \\
\hline & $r$ & Null & - & - & - & - & - & - & 10263 & 1686 \\
\hline & $a$ & Null & - & - & - & - & - & - & 34588 & 4413 \\
\hline
\end{tabular}

summer radiation was greater for regeneration (optimum at $7.3 \mathrm{~kW} \mathrm{~h} \mathrm{~m}^{-2}$ ) than for the adults (optimum at $6.6 \mathrm{~kW}$ $\mathrm{h} \mathrm{m}^{-2}$ ). Q. faginea showed a weak response (AIC with respect to the null model $=7$ ) along CCA axes and main environmental gradients, and thus the differences between optima of $r$ and $a$ could not be tested.

We found a significant effect of the vegetation cover (total stand basal area) on species regeneration (Appendix S4). For pines, $P$. pinea regeneration abundance showed a positive linear response to increased stand basal area. The other species showed a unimodal response, with optimum for regeneration at low values of the stand basal area $\left(13.8 \mathrm{~m}^{2} \mathrm{ha}^{-1}\right.$ ) for P. halepensis, medium (ca. $30 \mathrm{~m}^{2} \mathrm{ha}^{-1}$ ) for $P$. pinaster and P. sylvestris, and high $\left(58 \mathrm{~m}^{2} \mathrm{ha}^{-1}\right)$ for $P$. nigra. For oak species, regeneration abundance showed a positive linear response to increased stand basal area for $Q$. canariensis and Q. faginea, while $Q$. ilex and $Q$. suber showed a unimodal response, with optima at 13.6 and $21.8 \mathrm{~m}^{2}$ ha $^{-1}$, respectively (Appendix S4).

When we tested (with the non-parametric ANOVA) for differences in species regeneration between the different habitats, we found that all pine species showed highest mean regeneration abundance in the Pinus habitat (Fig. 4a). For P. nigra, P. pinea and P. pinaster, regeneration under pines did not significantly differ from that found in Mixed Quercus-Pinus habitats. However, pine regeneration found in the habitats dominated by Quercus and Other species was very scarce $(<12 \%$ of SSFI plots with regeneration) in all species. For oak species, regeneration of Q. suber, Q. canariensis and Q. pyrenaica was found at the highest frequency and with a greater mean abundance in the Quercus habitat (although for Q. canariensis and Q. pyrenaica reliable statistical comparisons could not be made due to the low number of cases) (Fig. 4b). Conversely, for Q. faginea and Q. ilex, regeneration was found in a higher proportion (ca. $40 \%$ of plots) in the Pinus habitat. Furthermore, Q. ilex showed the highest mean regeneration abundance under Mixed Quercus-Pinus forests (Fig. 4b).

For Q. ilex, habitat type and the temperature of the coldest month (TCM, i.e. the factor that best explained species regeneration distribution, see Table 2) showed a highly significant $(P<0.002)$ interaction effect on the abundance of regeneration, suggesting that the canopy type conditioned the effect of extreme temperatures on the regeneration of this species. When all main effects (i.e. the different habitats and TCM) and their interactions were considered, a highly significant interaction effect between Pinus cover and the TCM variable emerged. Together with the mixed Pinus-Quercus cover type (Fig. $4 \mathrm{~b}$ ), this was the unique positive effect (relative to that of a reference conspecific cover) detected on $Q$. ilex regeneration. These results suggest that extreme temperatures could be better tolerated by Q. ilex seedlings under Pinus canopies than in the other habitats studied, including those dominated by conspecific adults. As shown in Fig. 5, Q. ilex regeneration reached environmentally more extreme (i.e. colder) areas than the adult trees. Specifically, $Q$. ilex regeneration showed its maximum at average values of the temperature (TCM) gradient, where Q. ilex, $P$. halepensis and P. pinaster adults co-occurred (mainly in mixed stands); while it expanded its distribution niche towards the coldest end (where $Q$. ilex adults were lacking), regenerating under the canopy of pines.

\section{Discussion}

\section{Drivers of regional-scale pine-oak distribution}

Pine and oak species segregate along altitudinal and latitudinal gradients that often correlate with resource variability (e.g. water availability) and environmental conditions (e.g. temperature or radiation) (Barton 1993; Purves et al. 2007). Climate was the main driver of the 

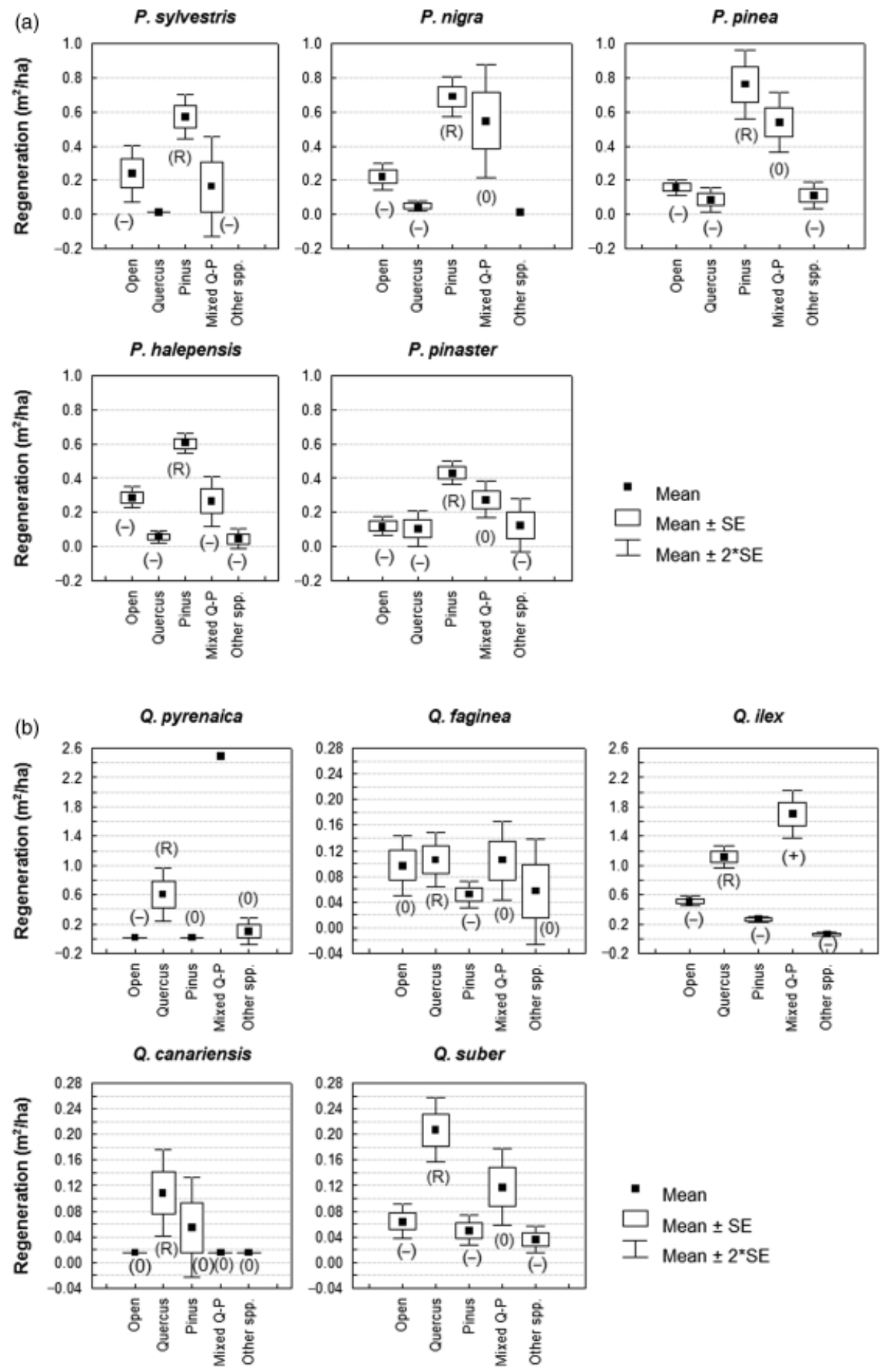

Fig. 4. Box-Whisker plots with mean \pm standard error (SE) of regeneration abundance $\left(\mathrm{m}^{2} \mathrm{ha}^{-1}\right)$ of pines $(\mathbf{a})$ and oaks (b) in different habitats: Open, Quercus, Pinus, Mixed Quercus-Pinus and Other spp. Regeneration abundance in each habitat is compared to the reference (R) habitat (that with conspecifics, i.e. Pinus or Quercus). Significant differences $(P<0.05)$ are indicated with $(+)$, when species regeneration is higher compared to the reference habitat, or with $(-)$ when it is lower; (0) indicates no significant differences, and no symbol is shown when the number of plots was too low to test for differences.

studied species distribution, while substrate (soil characteristics) and topography were secondary, but relevant for some species. Pines were able to reach the more severe (i.e. colder, drier) environments; for example P. sylvestris and $P$. nigra were dominant at the coldest end in montane areas (Castro et al. 2004), while P. halepensis and P. pinaster 


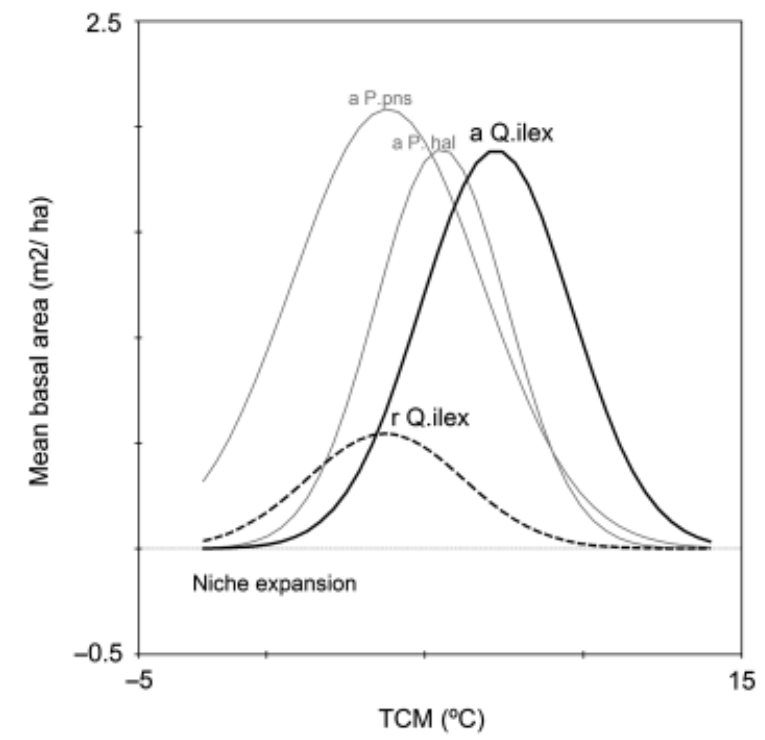

Fig. 5. Q. ilex adult distribution (bold line) and regeneration niche (dashed line) along the temperature gradient of the coldest month (TCM, $\left.{ }^{\circ} \mathrm{C}\right)$. Q. ilex regenerates towards colder areas under the canopy of $P$. halepensis and $P$. pinaster (grey bold lines), expanding its realized niche towards areas with more environmental severity.

prevailed towards drier conditions (Zavala \& Zea 2004). In general, oak species were more abundant in the milder, wetter winter lowland areas, except for Q. ilex, which showed a broad distribution, reaching both drier and colder areas. Soil properties (calcium content and depth) appear to be a key factor for some species, such as $P$. halepensis, associated with soils with high base saturation and calcium content. In contrast, Q. suber and $Q$. canariensis were associated with acidic substrates (Serrasolses et al. 2009).

A long history of forest management has shaped the present Mediterranean forest composition (Blondel \& Aronson 1995). Pine forests were a natural feature of the landscape in southern Spain in the past (Gómez et al. 2005), particularly when mixed with oaks (Carrión et al. 2000), but they have been much deforested during the last two millennia. Nonetheless, the wide expanses found today are a result of the extensive pine plantation carried out during the 20th century following an edaphoclimatic pattern (Pausas et al. 2004). In another example, lastcentury forest management has favoured Q. suber for cork production at the expense of other species, such as $Q$. canariensis, which in the absence of human influence would probably have a broader distribution (Urbieta et al. 2008b). Acknowledging the influence of human activities on present forest composition, we propose that the different species ability to cope with environmental constraints has contributed to defining present-day species ranges. For example, the different tolerance of pines to low temperature (frost mortality of seedlings) might explain their altitudinal distribution (e.g. Fernández et al. 2003); while in drier lowland areas, species tolerance to drought has been found to be the key mechanism that controls stand structure (Zavala \& Zea 2004). The ability to recover after disturbances, like fire, might also explain species distribution patterns (Broncano et al. 2005). For example, fire survival strategies of $P$. halepensis and $P$. pinaster, with serotinous cones and direct regeneration after fire, might have favoured them on fire-prone areas over $P$. nigra, $P$. sylvestris or $P$. pinea, which show lower post-fire survival (Tapias et al. 2001).

The differential distribution patterns along aridity and temperature gradients between Mediterranean oaks seem to be controlled by their different leaf habit and tissue water relationships (e.g. Nardini \& Tyree 1999; Quero et al. 2008). Our results showed that the distribution of evergreen species (particularly Q. ilex) reached conditions that are drier and colder than those of deciduous (Q. pyrenaica) or semi-deciduous oaks (Q. faginea and $Q$. canariensis). This could be because under water stress the higher cell wall rigidity of evergreen leaves enables them to avoid excessive water loss (Corcuera et al. 2002). Moreover, under mild freezing conditions, common in winter, the maintenance of both photosynthetic and vascular function allows the evergreen species to continue photosynthesis and gas exchange throughout winter, providing an advantage over their deciduous congeners (Cavender-Bares et al. 2005).

\section{Pine and oak forest regeneration patterns}

Forest inventory data revealed an overall scarce regeneration in pine and oak forests of southern Spain, as reported in other Mediterranean areas (e.g. Acácio et al. 2008; Plieninger et al. 2010). The spatial and temporal changes in environmental conditions (mainly light and water availability) that occur in heterogeneous Mediterranean landscapes provide relatively few "safe sites" for seedling establishment and survival (Gómez-Aparicio et al. 2005; Pulido \& Díaz 2005; Pons \& Pausas 2006). Among the experimentally identified main causes of recruitment failure in Mediterranean forests, a reduction in seed crop (e.g. in P. pinea, Mutke et al. 2005), a failure of available seeds combined with dispersal limitation (found in several oak species by Pulido \& Díaz 2005; Pérez-Ramos et al. 2008; Espelta et al. 2009), the effects of distribution of microsites and factors negatively affecting seedling growth and mortality (Pérez-Ramos et al. 2010) are particularly relevant. In particular, summer drought is commonly found to be a major limiting factor for seedling survival in oaks (e.g. Espelta et al. 1995; Gómez-Aparicio 
et al. 2008) and pines (e.g. Castro et al. 2004; Mendoza et al. 2009), with shade conditions alleviating drought stress for seedlings, but potentially leading to light limitation (Quero et al. 2006). For example, in the species with the lowest proportion of regeneration in the study area $-Q$. suber and $Q$. canariensis - their recruitment is limited by a combination of factors: the high post-dispersal acorn predation, mainly by rodents (Pérez-Ramos et al. 2008), and sequential winter soil waterlogging and summer drought (Urbieta et al. 2008a). Furthermore, herbivory damage by insects, rodents or ungulates affecting both pines and oaks (e.g. Gómez et al. 2001, 2003), together with negative effects of some silvicultural practices such as overstorey clearcuts and soil treatments (e.g. del Cerro Barja et al. 2009), all hamper the natural regeneration of Mediterranean forests.

For the five pine species, mean regeneration abundance was highest under pine forests. Oak regeneration was mainly associated with some degree of canopy cover. As shown by many field experiments, the establishment of Mediterranean oaks is favoured under some degree of vegetation cover (Espelta et al. 1995; Gómez-Aparicio et al. 2008; Mendoza et al. 2009). The regeneration of $Q$. pyrenaica, Q. suber, and Q. canariensis was more frequent and abundant under the canopy of their congeners, whereas for $Q$. faginea and $Q$. ilex a higher proportion of recruits was inventoried under pine-dominated stands and mixed oak-pine forests. These findings support those of other studies, which reported evidence of pines regenerating mostly in pine-dominated fragments or open areas, and oak species regenerating under both oak- and pine-dominated stands (e.g. Galindo-Jaimes et al. 2002; Pons \& Pausas 2006).

\section{Niche expansion of $Q$. ilex in pine-dominated stands}

Q. ilex regeneration abundance was displaced towards colder temperature areas, compared to the adult distribution optimum; precisely those most extreme areas with $Q$. ilex regeneration where under the canopy of pine forests (Fig. 5). This pattern suggests an upward shift of $Q$. ilex towards areas with more stressful conditions - i.e. colder and with higher summer radiation - but also with an increased summer precipitation regime.

The canopy of pines could mitigate the low temperatures and high radiation levels that hamper Q. ilex seedling survival (Sánchez-Gómez et al. 2006). Oaks can colonize the understorey of pine forests through jay-mediated dispersal of acorns (Mosandl \& Kleinert 1998; Gómez 2003), and seedlings survive better under the moderate radiation conditions found under the canopy of pines (Lookingbill \& Zavala 2000). Furthermore, in these mountain areas, oak regeneration would benefit from higher water availability in summer (normally in the form of storms) (Mendoza et al. 2009). Similarly, the combination of dispersal by jays preferring pine forests and the benefit of the shaded, understorey habitats under a dry Mediterranean-type climate has been noted as crucial for the conservation of fragmented southern populations of Fagus sylvatica (Kunstler et al. 2007). The improvement in soil fertility and microclimate provided by the $P$. halepensis canopy is known to facilitate establishment of perennial grasses and shrubs (e.g. Arrieta $\delta$ Suárez 2006). However, negative effects on species richness and plant establishment in the understorey have also been reported (Bellot et al. 2004). In some cases, the regeneration of oaks in pine-dominated stands originates through sprouting from old remnant trees suppressed by recurrent clipping, fire or browsing (Retana et al. 1992; Broncano et al. 2005). It is frequent that in abandoned old pine plantations, currently non-profitable for timber, their high density and dense shade impede the growth and development of oak saplings (Gómez-Aparicio et al. 2009), which persist suppressed and form a seedling bank (Gracia et al. 2001).

Mediterranean pine and oak forest dynamics remain uncertain under the warmer and drier environmental conditions predicted by climate-change projections (IPCC 2007). A similar mismatch between regeneration and adult distribution has been found in 13 forest species in the French mountains, and has been attributed to the effect of global warming (Lenoir et al. 2009). In the present study, we did not test climate change effects because of insufficient data.

Current management trends in Southern Spain are oriented towards conservation, and include thinning of pine plantations to promote native oak regeneration. Nonetheless, given the reduced demand for wood products (e.g. timber), new management options, biodiversity conservation guidelines and recent regeneration problems detected in pine and oak stands, we can foresee new shifts in Mediterranean forest composition. Further improvement in the understanding of forest structure and facilitation processes along environmental gradients will have direct relevance in the development of tools for ecosystem restoration and in anticipating the responses of plant species and communities to key drivers of environmental change.

\section{Acknowledgements}

We are grateful to Javier Quijada and José Manuel Moreira (REDIAM), José A. Villanueva (MMA) and Diego de la Rosa (IRNAS) for providing the environmental data, SSFI data and soil maps, respectively. Adela Moreno and Miguel A. Lorenzo helped with soil data processing. 
Comments by three anonymous reviewers greatly improved the original manuscript. This study was supported by grant FPI-MEC to IRU, by the coordinated Spanish MEC projects, Dinamed (CGL2005-05830-C03) and Interbos (CGL2008-04503-C03), and by European FEDER funds. This research is part of the GLOBIMED (http:// www.globimed.net) network on forest ecology.

\section{References}

Acácio, V., Holmgren, M., Jansen, P.A. \& Schrotter, O. 2008. Multiple recruitment limitation causes arrested succession in Mediterranean cork oak systems. Ecosystems 10: 1220-1230.

Akaike, H. 1992. Information theory and an extension of the maximum likelihood principle. In: Kotz, S. \& Johnson, N. (eds.) Breakthroughs in statistics. Vol. 1, pp. 610-624. SpringerVerlag, London, UK.

Arrieta, S. \& Suárez, F. 2006. Scots pine (Pinus sylvestris L.) plantations contribute to the regeneration of holly (Ilex aquifolium L.) in Mediterranean central Spain. European Journal of Forest Research 125: 271-279.

Bansal, S. \& Germino, J. 2010. Variation in ecophysiological properties among conifers at an ecotonal boundary: comparison of establishing seedlings and established adults at timberline. Journal of Vegetation Science 21: 133-142.

Baraza, E., Zamora, R. \& Hódar, J.A. 2006. Conditional outcomes in plant-herbivore interactions: neighbours matters. Oikos 113: 148-156.

Barton, A.M. 1993. Factors controlling plant distributions: drought, competition, and fire in montane pines in Arizona. Ecological Monographs 63: 367-397.

Bellot, J., Maestre, F.T., Chirino, E., Hernández, N. \& Ortiz de Urbina, J.M. 2004. Afforestation with Pinus halepensis reduces native shrub performance in a Mediterranean semiarid area. Acta Oecologica 25: 7-15.

Blondel, J. \& Aronson, J. 1995. Biodiversity and ecosystem function in the Mediterranean basin: human and nonhuman determinants. In: Davis, G.W. \& Richardson, D.M. (eds.) Mediterranean-type ecosystems: the function of biodiversity. pp. 43-119. Springer Verlag, Berlin, DE.

Borcard, D., Legendre, P. \& Drapeau, P. 1992. Partialling out the spatial component of ecological variation. Ecology 73 : 1045-1055.

Broncano, M.J., Retana, J. \& Rodrigo, A. 2005. Predicting the recovery of Pinus halepensis and Quercus ilex forests after a large wildfire in northeastern Spain. Plant Ecology 180: 47-56.

Callaway, R.M. \& Walker, L.R. 1997. Competition and facilitation: a synthetic approach to interactions in plant communities. Ecology 78: 1958-1965.

Carrión, J.S., Navarro, C., Navarro, J. \& Munuera, M. 2000. The distribution of cluster pine (Pinus pinaster) in Spain as derived from palaeoecological data: relationships with phytosociological classification. The Holocene 10: 243-252.
Castro, J., Zamora, R., Hódar, J.A. \& Gómez, J.M. 2004. Seedling establishment of a boreal tree species (Pinus sylvestris) at its southernmost distribution limit: consequences of being in a marginal, Mediterranean habitat. Journal of Ecology 92: 266-277.

Cavender-Bares, J. \& Bazzaz, F.A. 2000. Changes in drought response strategies with ontogeny in Quercus rubra: implications for scaling from seedlings to mature trees. Oecologia 124: 8-18.

Cavender-Bares, J., Cortes, P., Rambal, S., Joffre, R., Miles, B. \& Rocheteau, A. 2005. Summer and winter sensitivity of leaves and xylem to minimum freezing temperatures: a comparison of co-occurring Mediterranean oaks that differ in leaf lifespan. New Phytologist 168: 597-612.

Corcuera, L., Camarero, J.J. \& Gil-Pelegrin, E. 2002. Functional groups in Quercus species derived from the analysis of pressure-volume curves. Trees - Structure and Function 16: 465-472.

Currie, D.J. \& Paquin, V. 1987. Large-scale biogeographical patterns of species richness of trees. Nature 329: 326-327.

del Cerro Barja, A., Lucas-Borja, M.E., Martínez Garcia, E., López Serrano, F.R., Andrés Abellán, M., García Morote, F.A. \& Navarro López, R. 2009. Influence of stand density and soil treatment on the Spanish Black Pine (Pinus nigra Arn. ssp. Salzmannii) regeneration in Spain. Investigación Agraria Sistemas y Recursos Forestales 18: 167-180.

Espelta, J.M., Riba, M. \& Retana, J. 1995. Patterns of seedling recruitment in West-Mediterranean Quercus ilex forest influenced by canopy development. Journal of Vegetation Science 6: 465-472.

Espelta, J.M., Cortés, P., Molowny-Horas, R. \& Retana, J. 2009. Acorn crop size and pre-dispersal predation determine inter-specific differences in the recruitment of cooccurring oaks. Oecologia 161: 559-568.

Fernández, M., Royo, A., Gil, L. \& Pardos, J.A. 2003. Effects of temperature on growth and stress hardening development of phytotron-grown seedlings of Aleppo pine (Pinus halepensis Mill.). Annals of Forest Science 60: 277-284.

Galindo-Jaimes, L., González-Espinosa, M., QuintanaAscencio, P. \& García-Barrios, L. 2002. Tree composition and structure in disturbed stands with varying dominance by Pinus spp. in the highlands of Chiapas, México. Plant Ecology 162: 259-272.

García, L.V. 2004. Escaping the Bonferroni iron claw in ecological studies. Oikos 105: 657-663.

Gómez, A., Vendramin, G.G., González-Martínez, S.C. \& Alía, R. 2005. Genetic diversity and differentiation of two Mediterranean pines (Pinus halepensis Mill. and Pinus pinaster Ait.) along a latitudinal cline using chloroplast microsatellite markers. Diversity o Distributions 11: 257-263.

Gómez, J.M. 2003. Spatial patterns in long-distance dispersal of Quercus ilex acorns by jays in a heterogeneous landscape. Ecography 26: 573-584.

Gómez, J.M, Hódar, J.A., Zamora, R., Castro, J. \& García, D. 2001. Ungulate damage on Scots pines in Mediterranean 
environments: effects of association with shrubs. Canadian Journal of Botany 79: 739-746.

Gómez, J.M., Garcia, D. \& Zamora, R. 2003. Impact of vertebrate acorn and seedling-predators on a Mediterranean Quercus pyrenaica forest. Forest Ecology $\theta$ Management 180: 125-134.

Gómez-Aparicio, L., Gómez, J.M. \& Zamora, R. 2005. Microhabitats shift rank in suitability for seedling establishment depending on habitat type and climate. Journal of Ecology 93: 1194-1202.

Gómez-Aparicio, L., Pérez-Ramos, I.M., Mendoza, I., Matías, L., Quero, J.L., Castro, J., Zamora, R. \& Marañón, T. 2008. Oak seedling survival and growth along resource gradients in Mediterranean forests: implications for regeneration under current and future environmental scenarios. Oikos 117: 1683-1699.

Gómez-Aparicio, L., Zavala, M.A., Bonet, F.J. \& Zamora, R. 2009. Are pine plantations valid tools for restoring Mediterranean forests? An assessment along abiotic and biotic gradients. Ecological Applications 19: 2124-2141.

Gracia, M., Retana, J. \& Pico, F.X. 2001. Seedling bank dynamics in managed holm oak (Quercus ilex) forests. Annals of Forest Science 58: 843-852.

Huston, M.A. 1994. Biological diversity: the coexistence of species in changing landscapes. Cambridge University Press, Cambridge, UK.

IPCC (Intergovernmental Panel on Climate Change). 2007. Climate change 2007: the physical science basis. In: Solomon, S. et al. (eds.) Contribution of working group I to the fourth assessment report of the IPCC. Cambridge University Press, Cambridge, UK and New York, NY, US.

JA (Junta de Andalucía). 2003. Ortofotografía Digital de Andalucía (color). Consejerías de Obras Públicas y Transporte, Medio Ambiente, y Agricultura y Pesca, Sevilla, ES.

Kohyama, T. 1993. Size-structured tree populations in gapdynamic forest - the forest architecture hypothesis for the stable coexistence of species. Journal of Ecology 81: 131-143.

Kolb, T.E. \& Stone, J.E. 2000. Differences in leaf gas exchange and water relations among species and tree sizes in an Arizona pine-oak forest. Tree Physiology 20: 1-12.

Kunstler, G., Thuiller, W., Curt, T., Bouchaud, M., Jouvie, R., Deruette, F. \& Lepart, T. 2007. Fagus sylvatica L. recruitment across a fragmented Mediterranean landscape, importance of long distance effective dispersal, abiotic conditions and biotic interactions. Diversity $\theta$ Distributions 13: 799-807.

Lenoir, J., Gégout, J.-C., Pierrat, J.-C., Bontemps, J.-D. \& Dhôte, J.-F. 2009. Differences between tree species seedling and adult altitudinal distribution in mountain forests during a recent warm period (1986-2006). Ecography 32: 765-777.

Leps, J. \& Smilauer, P. 2003. Multivariate analysis of ecological data Using CANOCO. Cambridge University Press, Cambridge, UK.

Lookingbill, T. \& Zavala, M.A. 2000. Spatial pattern of Quercus ilex and Quercus pubescens recruitment in Pinus halepensis dominated woodlands. Journal of Vegetation Science 11: 607-612.
Maestre, F.T. \& Cortina, J. 2004. Are Pinus halepensis plantations useful as a restoration tool in semiarid Mediterranean areas? Forest Ecology $\theta$ Management 198: 303-317.

Mediavilla, S. \& Escudero, A. 2004. Stomatal responses to drought of mature trees and seedlings of two co-occurring Mediterranean oaks. Forest Ecology e Management 187: 281-294.

Mendoza, I., Gómez-Aparicio, L., Zamora, R. \& Matías, L. 2009. Recruitment limitation of forest communities in a degraded Mediterranean landscape. Journal of Vegetation Science 20: 367-376.

MMA (Ministerio de Medio Ambiente). 1996. Segundo Inventario Forestal Nacional (1986-1996): bases de datos e información cartográfica. Banco de Datos de la Naturaleza. Ministerio de Medio Ambiente, Madrid, ES.

Mosandl, R. \& Kleinert, A. 1998. Development of oaks (Quercus petraea (Matt.) Liebl.) emerged from bird-dispersed seeds under old-growth pine (Pinus silvestris L.) stands. Forest Ecology $\theta$ Management 106: 35-44.

Mutke, S., Gordo, J. \& Gil, L. 2005. Variability of Mediterranean stone pine cone production: yield loss as response to climate change. Agricultural and Forest Meteorology 132: 263-272.

Nardini, A. \& Tyree, M.T. 1999. Root and shoot hydraulic conductance of seven Quercus species. Annals of Forest Science 56: 371-377.

Økland, R.H. \& Eilertsen, O. 1994. Canonical correspondence analysis with variation partitioning: some comments and application. Journal of Vegetation Science 5: 117-126.

Onaindia, M. \& Mitxelena, A. 2009. Potential use of pine plantations to restore native forests in a highly fragmented river basin. Annals of Forest Science 66: 305-312.

Pausas, J.G., Bladé, C., Valdecantos, A., Seva, J.P., Fuentes, D., Alloza, J.A., Vilagrosa, A., Bautista, S., Cortina, J. \& Vallejo, R. 2004. Pines and oaks in the restoration of Mediterranean landscapes in Spain: new perspectives for an old practice - a review. Plant Ecology 171: 209-220.

Pérez-Ramos, I.M., Urbieta, I.R., Marañón, T., Zavala, M.A. \& Kobe, R.K. 2008. Seed removal in two coexisting oak species: ecological consequences of seed size, plant cover and seed-drop timing. Oikos 117: 1386-1396.

Pérez-Ramos, I.M., Gómez-Aparicio, L., Villar, R., García, L.V. \& Marañón, T. 2010. Seedling growth and morphology of three oak species along field resource gradients and seed mass variation: a seedling age-dependent response. Journal of Vegetation Science 21: 419-437.

Plieninger, T., Rolo, V. \& Moreno, G. 2010. Large-scale patterns of Quercus ilex, Quercus suber, and Quercus pyrenaica regeneration in central-western Spain. Ecosystems 13: 644-660.

Pons, J. \& Pausas, J.G. 2006. Oak regeneration in heterogeneous landscapes: the case of fragmented Quercus suber forests in the eastern Iberian Peninsula. Forest Ecology $\theta$ Management 231: 196-204.

Pulido, F.J. \& Díaz, M. 2005. Regeneration of a Mediterranean oak: a whole-cycle approach. Ecoscience 12: 92-102.

Pulido, F.J., Díaz, M. \& Hidalgo de Trucios, S.J. 2001. Size structure and regeneration of Spanish holm oak Quercus ilex 
forest and dehesas: effects of agroforestry use on their longterm sustainability. Forest Ecology e Management 146: 1-13.

Purves, D.W., Zavala, M.A., Ogle, K., Prieto, F. \& Rey Benayas, J.M. 2007. Environmental heterogeneity, bird-mediated directed dispersal, and oak woodland dynamics in Mediterranean Spain. Ecological Monographs 77: 77-97.

Quero, J.L., Villar, R., Marañón, T. \& Zamora, R. 2006. Interactions of drought and shade effects on seedlings of four Quercus species: physiological and structural leaf responses. New Phytologist 170: 819-834.

Quero, J.L., Villar, R., Marañón, T., Zamora, R., Vega, D. \& Sack, L. 2008. Relating leaf photosynthetic rate to whole plant growth: drought and shade effects on seedlings of four Quercus species. Functional Plant Biology 35: 725-737.

Retana, J., Riba, M., Castell, C. \& Espelta, J.M. 1992. Regeneration by sprouting of holm-oak (Quercus ilex) stands exploited by selection thinning. Vegetatio 99/100: 355-364.

Sánchez-Gómez, D., Zavala, M.A. \& Valladares, F. 2006. Seedling survival responses to irradiance are differentially influenced by low-water availability in four tree species of the Iberian cool temperate-Mediterranean ecotone. Acta Oecologica 30: 322-332.

Schupp, E.W. 1995. Seed-seedling conflicts, habitat choice, and patterns of plant recruitment. American Journal of Botany 82: 399-409.

Serrasolses, I., Pérez-Devesa, M., Vilagrosa, A., Pausas, J.G., Sauras, T., Cortina, J. \& Vallejo, V.R. 2009. Soil properties constraining cork oak distribution. In: Aronson, J., Pereira, J.S. \& Pausas, J.G. (eds.) Cork oak woodlands on the edge. Ecology, adaptive management, and restoration. pp. 89-101. Island Press, Washington, DC, US.

Svenning, J.C. \& Skov, F. 2005. The relative roles of environment and history as controls of tree species composition and richness in Europe. Journal of Biogeography 32: 1019-1033.

Tapias, R., Gil, L., Fuentes-Utrilla, P. \& Pardos, J.A. 2001. Canopy seed banks in Mediterranean pines of southeastern Spain: a comparison between Pinus halepensis Mill., P. pinaster Ait., P. nigra Arn. and P. pinea L. Journal of Ecology 89: 629-638.

ter Braak, C.J.F. 1986. Canonical correspondence analysis: a new eigenvector technique for multivariate direct gradient analysis. Ecology 67: 1167-1179.

ter Braak, C.J.F. \& Smilauer, P. 2002. CANOCO reference manual and CanoDraw for Windows user's guide: software for canonical community ordination v.4.5. Microcomputer Power, Ithaca, NY, US.

Thornthwaite, C.W. 1948. An approach toward a rational classification of climate. Geographical Review 38: 55-94.

Urbieta, I.R., Pérez-Ramos, I.M., Zavala, M.A., Marañón, T. \& Kobe, R.K. 2008a. Soil water content and emergence time control seedling establishment in three co-occurring Mediterranean oak species. Canadian Journal of Forest Research 38: 2382-2393.

Urbieta, I.R., Zavala, M.A. \& Marañón, T. 2008b. Human and non-human determinants of forest composition in southern Spain: evidence of shifts toward cork oak dominance as a result of management over the past century. Journal of Biogeography 35: 1688-1700.

Zavala, M.A. \& Zea, E. 2004. Mechanisms maintaining biodiversity in Mediterranean pine-oak forests: insights from a spatial simulation model. Plant Ecology 171: 197-207.

\section{Supporting Information}

Additional supporting information may be found in the online version of this article:

Appendix S1. Pine and oak species abundance (mean basal area, $\mathrm{m}^{2} \mathrm{ha}^{-1}$ ) along CCA Axis 2 .

Appendix S2. Best model fits and parameters for species overall abundance in relation to the principal CCA axes and the main environmental variables.

Appendix S3. Mean and range values of the environmental variables characterizing the distribution of five pine and oak species in southern Spain.

Appendix S4. Model fit and parameters for species regeneration abundance in relation to stand basal area.

Please note: Wiley-Blackwell are not responsible for the content or functionality of any supporting materials supplied by the authors. Any queries (other than missing material) should be directed to the corresponding author for the article. 